\title{
Effect of Hot Band Annealing Temperature on the Magnetic Properties of Low-carbon Electrical Steels
}

\section{Chun-Kan HOU}

Department of Mechanical Engineering, National Yunlin Institute of Technology, 123 University Road, Section 3, Touliu, Yunlin 640, Taiwan, Republic of China.

(Received on October 2, 1995; accepted in final form on November 29, 1995)

The effect of hot band annealing temperature, range from $700-1000^{\circ} \mathrm{C}$, on the magnetic properties of low-carbon electrical steels measured at 10,15 and $17 \mathrm{kG}$ inductions have been investigated. The grain microstructures of hot bands were changed by annealing at various temperature. Small grains are observed in the as hot-rolled band and hot band annealed at $700^{\circ} \mathrm{C}$. Large columnar grains are observed in the hot band annealed at $800^{\circ} \mathrm{C}$. Duplex structure with fine grains at the central portion of the plate and large columnar grains near the surface are observed in the hot band annealed at $900^{\circ} \mathrm{C}$. Uniform medium size grains are observed in the hot band annealed at $1000^{\circ} \mathrm{C}$. In addition, the size of manganese sulfide inclusions in the hot bands increased with increasing annealing temperature. After final annealing at $820^{\circ} \mathrm{C}$ for $1 \mathrm{~min}$, grain size of low-carbon electrical steels increased with increasing hot band annealing temperature. After final annealing, low-carbon electrical steel with hot band annealing at $800^{\circ} \mathrm{C}$ developed favorable texture for magnetic properties. At three different inductions, ac core loss and hysteresis loss decreased with increasing hot band annealing temperature in $700-900^{\circ} \mathrm{C}$. At $10 \mathrm{kG}$ induction, ac and dc permeability increased with increasing hot band annealing temperature. Low-carbon electrical steel with hot band annealing at $800^{\circ} \mathrm{C}$ exhibited maximum ac and dc permeability under $15 \mathrm{kG}$ induction. However, the steel with hot band annealing at $900^{\circ} \mathrm{C}$ obtained maximum ac and dc permeability and maximum magnetic flux density under $17 \mathrm{kG}$ induction. Magnetic properties of the steel were improved when hot bands were annealed at temperature higher than $800^{\circ} \mathrm{C}$, when it was compared with the as hot-rolled steel.

KEY WORDS: electrical steel; magnetic properties; core loss; hysteresis loss; permeability; texture; grain size.

\section{Introduction}

Low-carbon electrical steels are used as core materials of fractional horsepower motors, small transformers and ballasts for the economic reason. ${ }^{1)}$ Alloy elements, such as silicon, aluminum, manganese and phosphorus are usually added to low-carbon electrical steels to increase their resistivity and to improve their magnetic properties. $^{2-5)}$ Impurities, such as carbon, nitrogen, sulfur and oxygen easily form carbides, nitrides, sulfides and oxides to impede the domain wall movement during magnetization and are deleterious to the magnetic properties of low-carbon electrical steels. Therefore, it is important to keep the impurity level as low as possible. Conventionally, critical strain temper rolling and decarburization annealing were adopted to decrease the carbon content to less than $0.005 \mathrm{wt} \%$ and to develop coarse grain structure to improve the magnetic properties of semi-processed lamination steels. However, with the progress of modern steelmaking technology and installation of Ruhrstahl-Heraeus vacuum degasser, carbon can be removed by vacuum degassing the molten steel so that the final decarburization step could be eliminated. ${ }^{6-8)}$ In the past two decades, continuousannealing equipments were widely installed around the world for the advantages of increasing the annealing temperature, shortening annealing time in a few minutes and improving the flatness and surface quality of coldrolled steel sheets. Due to the progress of steelmaking and continuous-annealing technologies, fully-processed low-carbon electrical steels could be produced by the integrated processes of basic oxygen furnace, RuhrstahlHeraeus vacuum degasser, continuous casting, continuous hot strip rolling mill, pickling, tandem cold mill, continuous annealing furnace and continuous coating line. ${ }^{9)}$

Many factors, such as alloy elements, impurities, inclusions, grain size and texture, affect the magnetic properties of low-carbon electrical steels. ${ }^{9-12)}$ Moreover, grain size, texture, and inclusion size of low-carbon electrical steels are influenced by their prior process variables. ${ }^{13-14)} \mathrm{H}$. Yashiki and A. Okamoto studied the effect of hot-band grain size on the magnetic properties of non-oriented electrical steels. ${ }^{15)}$ They found that core loss decreased with increasing hot band grain size. Hot band annealing could change the grain structure and was conducted in producing high grade non-oriented electrical steels. On the other hand, hot band annealing was not adopted in producing fully-processed low-carbon electrical steels for the economic reason. There were few 
reports concerning the effect of hot band annealing temperature on the hot band grain structure and magnetic properties of fully-processed low-carbon electrical steels. ${ }^{15)}$ Especially, effect of hot band annealing at temperature higher than the ferrite to austenite phase transformation temperature on the magnetic properties of fully-processed low-carbon electrical steels was not reported yet.

In our earlier work, we studied the effects of alloy elements and process variables on the magnetic properties of low-carbon electrical steels. ${ }^{16-21)}$ It stimulates us to study the effect of hot band annealing temperature on the hot band grain structure and the magnetic properties of low-carbon electrical steels. In this study, the hot bands were annealed at various temperature, range from $700-1000^{\circ} \mathrm{C}$, to change their grain microstructure and inclusion size. Ac core loss, hysteresis loss, apparent eddy current loss, ac and dc permeability were measured at 10,15 and $17 \mathrm{kG}$ inductions. Furthermore, magnetic flux density was measured at $5000 \mathrm{~A} / \mathrm{M}$ field strength. The magnetic properties of steel without hot band annealing and steels with hot band annealing at various temperature were compared. After final annealing at $820^{\circ} \mathrm{C}$ for $1 \mathrm{~min}$, the grain size and texture of low-carbon electrical steels were also measured. The mechanisms that hot band grain microstructure and size of manganese sulfide inclusions affected the final grain size, texture, and magnetic properties of low-carbon electrical steels were explained.

\section{Experimental Procedure}

Hot-rolled band of commercial low-carbon electrical steel was used as the starting material. Table 1 lists the chemical composition of the low-carbon electrical steel. The hot-rolled band of low-carbon electrical steel was produced by basic oxygen converter, Ruhrstahl-Heraeus vacuum degasser, continuous caster, and continuous hot

Table 1. Chemical composition of low-carbon electrical steel. $(w t \%)$

\begin{tabular}{cccccccc}
\hline Steel & $\mathrm{C}$ & $\mathrm{Si}$ & $\mathrm{Mn}$ & $\mathrm{P}$ & $\mathrm{S}$ & tot. Al & $\mathrm{N}$ \\
\hline ESHR1 & 0.0023 & 0.31 & 0.22 & 0.072 & 0.0070 & 0.0020 & 0.0018 \\
\hline
\end{tabular}

strip mill. The thickness of the hot bands was $2.3 \mathrm{~mm}$. The heat treatment process of low-carbon electrical steels is shown in Fig. 1. The hot-rolled bands were put into an electrical box furnace and annealed at 700, 800, 900 and $1000^{\circ} \mathrm{C}$ for $15 \mathrm{~min}$ followed by air cooling. For the comparison, the as hot-rolled band was also studied. The as hot-rolled band and annealed hot bands were immersed in a hydrochloride acid and cold-rolled to a final thickness of $0.5 \mathrm{~mm}$ by a laboratory four-high pilot cold-rolled mill. Then, the cold-rolled steel sheets were cut into $150 \mathrm{~mm} \times 300 \mathrm{~mm}$ sheets both in longitudinal and transverse directions with respect to the rolling direction and annealed in a salt bath furnace set at $820^{\circ} \mathrm{C}$ for $1 \mathrm{~min}$.

After annealing, the cold-rolled steel sheets were cut into $0.5 \mathrm{~mm} \times 30 \mathrm{~mm} \times 280 \mathrm{~mm}$ coupons in both longitudinal and transverse directions with respect to the rolling direction. Sixteen coupons of half in longitudinal direction and half in transverse direction were stacked in a $25 \mathrm{~cm}$ Epstein test frame to measure ac and $\mathrm{dc}$ magnetic properties. The ac core loss and ac permeability were tested at 10,15 and $17 \mathrm{kG}$ inductions and $50 \mathrm{~Hz}$. Magnetic flux density was also measured with magnetic field strength set at $5000 \mathrm{~A} / \mathrm{M}$. The dc hysteresis loops with maximum flux density at 10,15 and $17 \mathrm{kG}$ were measured to calculate hysteresis loss and dc permeability. Apparent eddy current loss was calculated by subtracting hysteresis loss from ac core loss.

Annealed specimens for texture examination were ground to quarter thickness away from surface and etched by a hydrogen peroxide solution mixed with several drops of hydrofluoric acid. The texture examination was performed by measurement of the inverse pole intensity of a specific plane using a Siemens D500 X-ray diffractometer and a texture attachment. A Mo target was used and operated at $40 \mathrm{kV}$ and $25 \mathrm{~mA}$. A slow scanning speed $0.5^{\circ} / \mathrm{min}$ was employed. A sintered iron powder specimen was used as a random sample. Inverse pole intensities of $\{110\},\{200\},\{211\}$ and $\{222\}$ planes parallel to the steel sheet surface were measured. Relative inverse pole intensity of a crystallographic plane, $\left(I / I_{\mathrm{R}}\right)_{h k l}$, was defined as the ratio of inverse pole intensity of the specific crystallographic plane of the specimen to that of the random sample. The microstructures of both hot bands

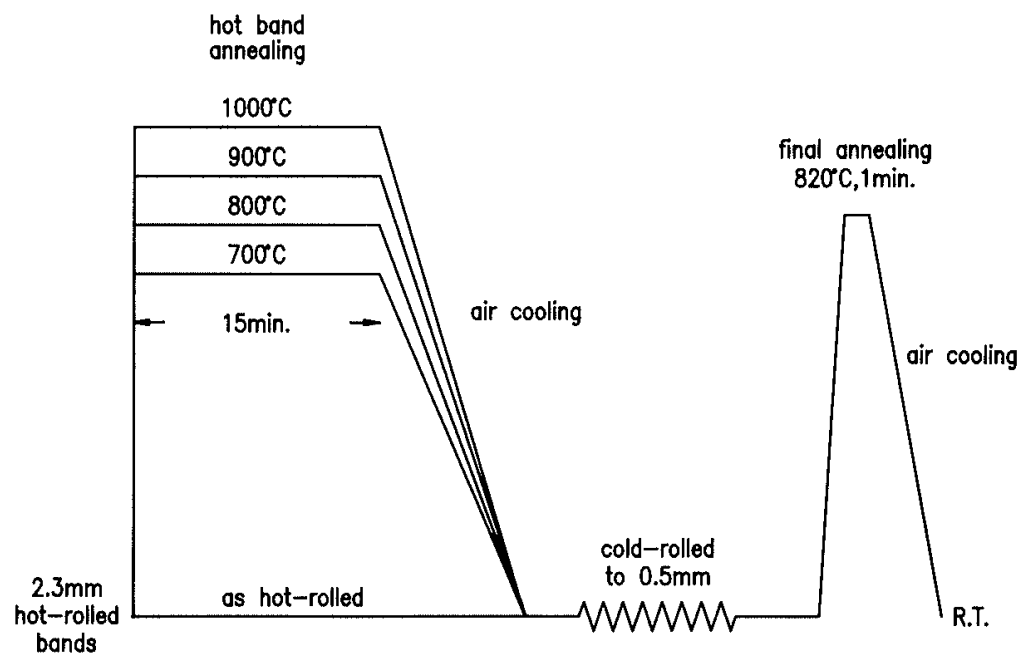

Fig. 1.

The schematic diagram showing the heat treatment process of low-carbon electrical steels. 
and cold-rolled steel sheets after annealing were examined by optical means. The grain size was measured by the intercept method based on ASTM Standard E-112. Both thin foil method and carbon replica method were performed to examine the manganese sulfide inclusions in the hot bands annealed at various temperature by using a Philips CM20 analytical transmission electron microscope with EDAX and operating at $200 \mathrm{kV}$.

\section{Results and Discussion}

\subsection{Microstructures of Hot Bands}

The optical microstructures of the specimens after hot band annealing at various temperature were shown in Fig. 2. The grain structures were changed by the hot band annealing temperature. Both as hot-rolled band and hot band annealed at $700^{\circ} \mathrm{C}$ had fine grain structure and the difference of their grain diameter was not obvious. Hot band annealed at $800^{\circ} \mathrm{C}$ had large columnar grain structure through the entire thickness. When hot band was annealed at $900^{\circ} \mathrm{C}$, some big columnar grains appeared near the surface and large proportion of fine grains appeared in the central portion of the plate. When hot band was annealed at $1000^{\circ} \mathrm{C}$, medium size equiaxial grain structure was observed through the whole thickness of plate. Manganese sulfide inclusions in the hot bands after annealing at various temperature were shown in Fig. 3. It was found that the size of manganese sulfide inclusions increased with increasing hot band annealing temperature. EDAX analysis of the inclusion was performed to confirm the existence of manganese sulfides.

The grain structures of hot bands were changed by annealing at various temperature. When hot band was annealed at $700^{\circ} \mathrm{C}$, grain growth of hot band was very sluggish. Therefore, its grain structure was similar to that of as hot-rolled band. When hot band was annealed at $800^{\circ} \mathrm{C}$, grain growth of hot band rapidly progressed from the surface to the center. So that, large columnar grain structure appeared. When hot band annealing temperature was increased to $900^{\circ} \mathrm{C}$, large proportion of ferrite at the center of the plate transformed to austenite. During air cooling, austenite transformed to fine ferrite again. However, small proportion of big columnar ferrite grain near the surface of the plate retained. Therefore, duplex structure with big columnar grain near the surface and fine grain structure in the central portion of the plate occurred. When hot band was annealed at $1000^{\circ} \mathrm{C}$, ferrite to austenite transformation occurred completely through the whole thickness of the hot band. During air cooling, austenite transformed to ferrite again. Since it was cooled
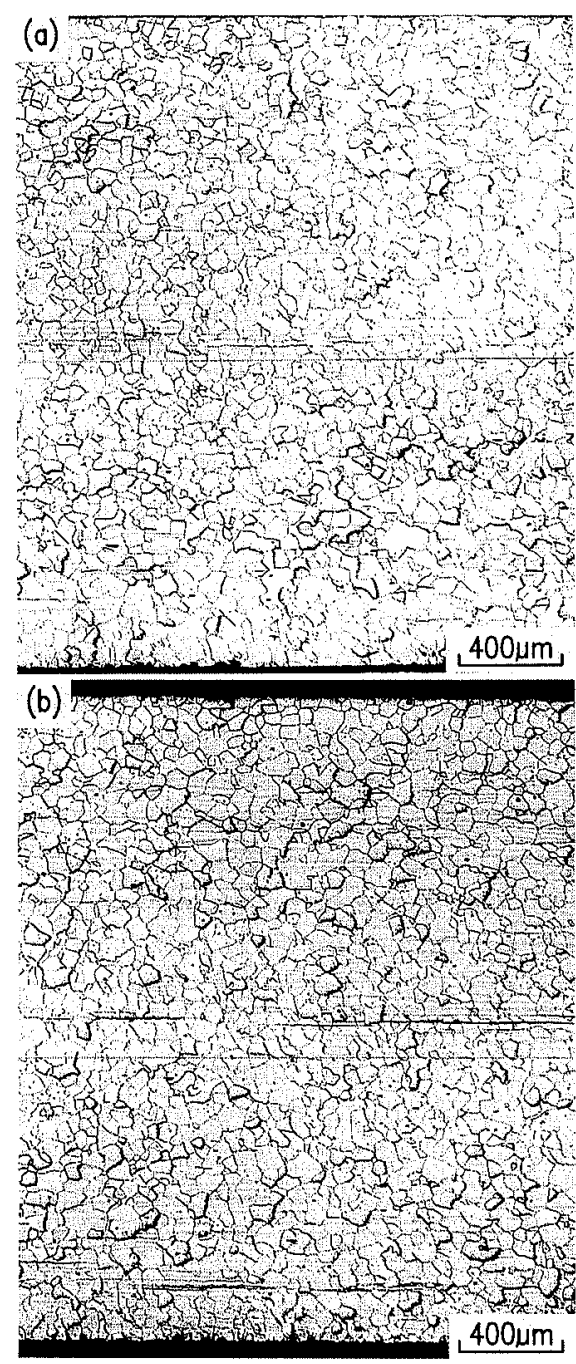
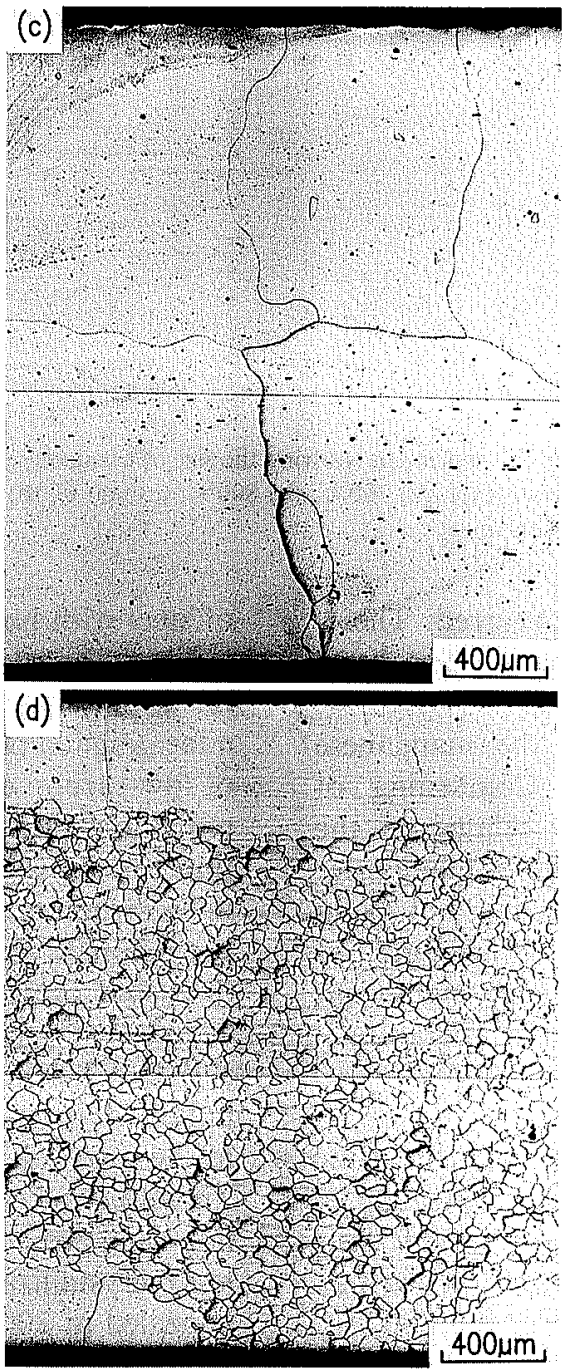

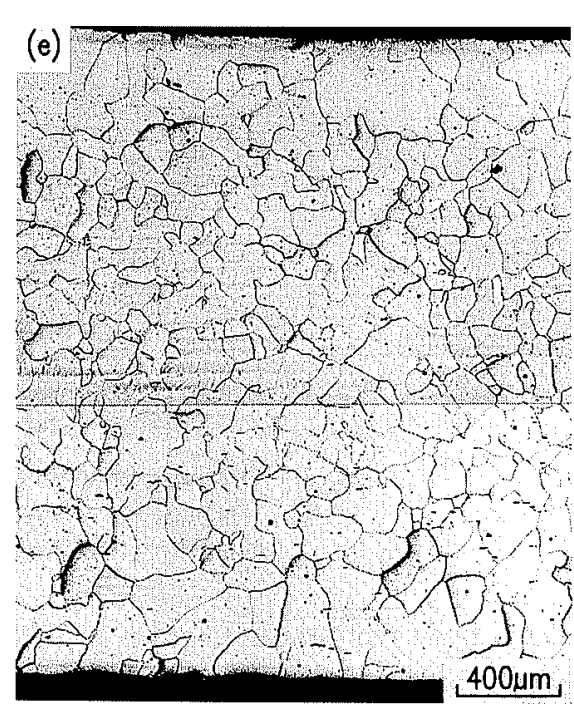

Fig. 2. The microstructures of hot band after annealing at various temperature for $15 \mathrm{~min}$ (a) as hot-rolled, (b) $700^{\circ} \mathrm{C}$, (c) $800^{\circ} \mathrm{C}$, (d) $900^{\circ} \mathrm{C}$ and (e) $1000^{\circ} \mathrm{C}$. 

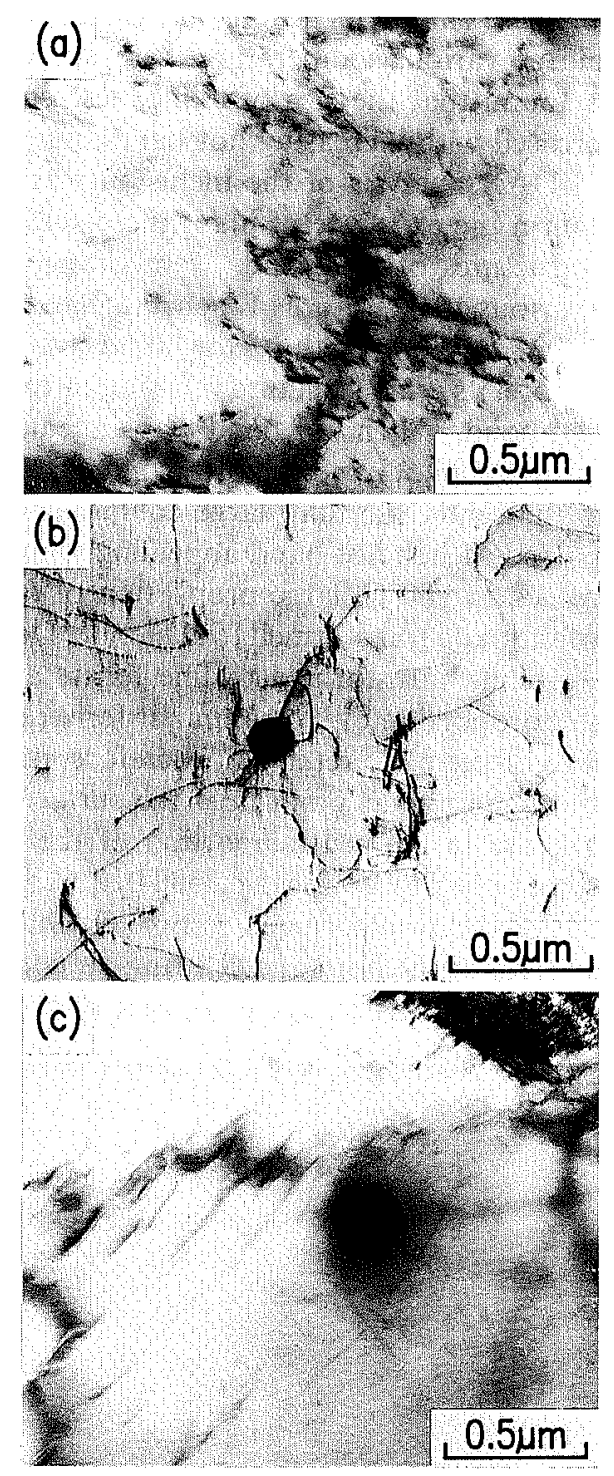

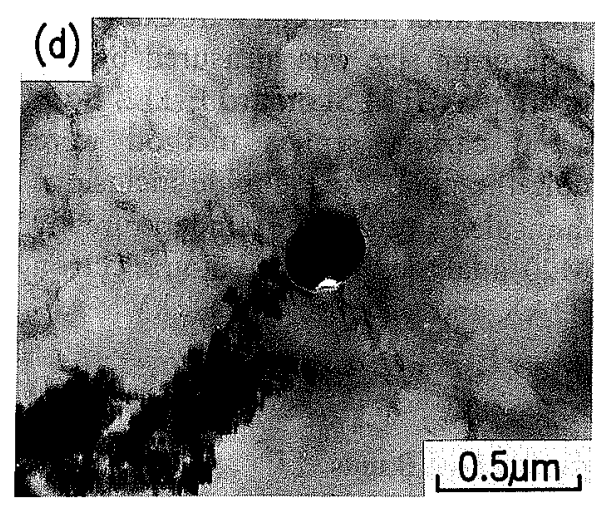

(e)

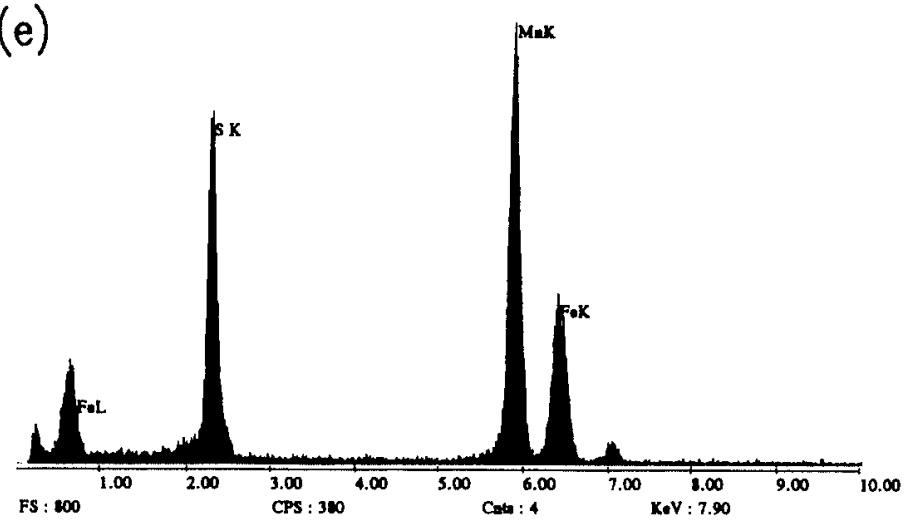

Fig. 3. TEM micrographs of thin foil specimens showing the size of manganese sulfide inclusions in hot bands after annealing at various temperature, (a) $700^{\circ} \mathrm{C}$, (b) $800^{\circ} \mathrm{C}$, (c) $900^{\circ} \mathrm{C}$, (d) $1000^{\circ} \mathrm{C}$ and (e) EDAX analysis of manganese sulfide inclusion in (c).

from high temperature, grain growth occurred. Therefore, its grain size was larger than that of hot band annealed at $700^{\circ} \mathrm{C}$.

Annealing temperature also affects the manganese sulfide inclusion size in hot band. Coarsening of manganese sulfide inclusion is closely related to the hot band annealing temperature. The size of manganese sulfide inclusions increased with increasing hot band annealing temperature. Particularly, coarsening of manganese sulfide inclusion will be more significant when the hot band is annealed at higher temperature.

\subsection{Grain Size}

The effect of hot band annealing temperature on the grain size of cold-rolled sheets after final annealing is shown in Fig. 4. The final grain size increased with increasing hot band annealing temperature. When hot bands was annealed at temperature higher than $800^{\circ} \mathrm{C}$, grain size rapidly increased with increasing hot band annealing temperature. However, the grain size of steel sheet without hot band annealing was larger than that of steel with hot band annealed at $700^{\circ} \mathrm{C}$.

Many factors, such as microstructures of hot bands, inclusion size, cold-rolled reduction, and continuous annealing temperature and time affect the final grain size of low-carbon electrical steels. In this study, cold-rolled reduction, and continuous annealing temperature and time of cold-rolled steel sheets were the same. Therefore, microstructure of hot bands and inclusion size were the predominate factors to influence the final grain size. As discussed previously, hot band annealing temperature change the grain structure and the size of manganese sulfide inclusions in the hot bands. Grain boundary of hot bands is a preferred nucleation site of recrystallization in the cold-rolled steel sheet during the final annealing. Therefore, after final annealing, steel with coarse grain hot-band structure would have coarse grain size due to less recrystallization nuclei. As shown in Fig. 2, hot band annealed at $800^{\circ} \mathrm{C}$ had the largest grain size. However, as shown in Fig. 4, steel with hot band annealing at $1000^{\circ} \mathrm{C}$ had the largest grain size after final annealing. It is found that the size of manganese sulfide inclusions 


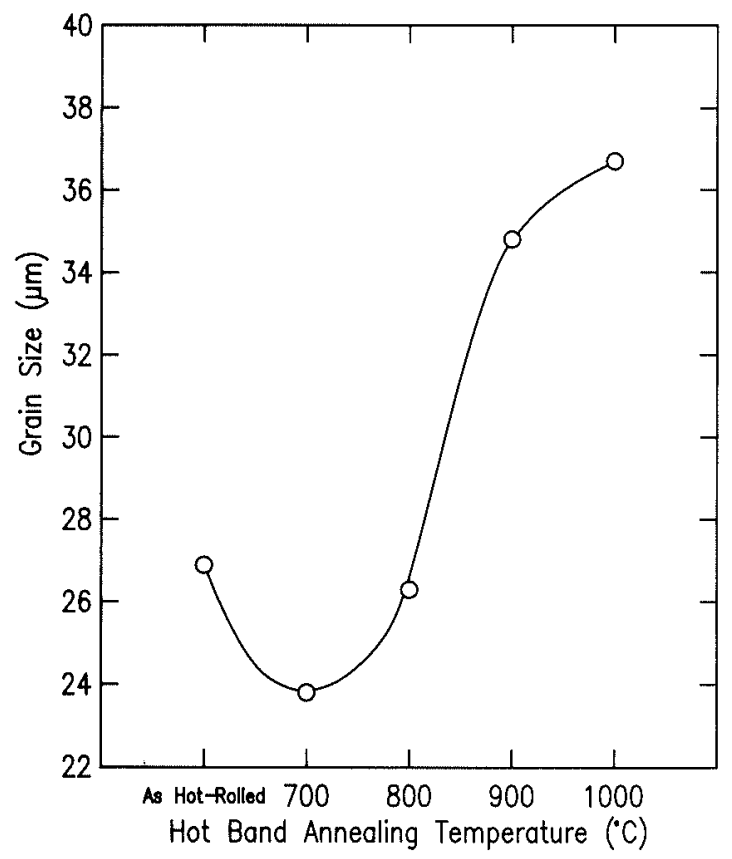

Fig. 4. Effect of hot band annealing temperature on the grain size of low-carbon electrical steels after simulated continuous annealing at $820^{\circ} \mathrm{C}$ for $1 \mathrm{~min}$.

plays an important role during final annealing. Manganese sulfide inclusions would prevent the movement of grain boundary and slow down the grain growth at the grain growth stage during final annealing. All hot bands have the same chemical composition. The volume fraction of manganese sulfide inclusion in all hot bands are the same. Based on Zener formula ${ }^{22)}$ the final grain size is proportional to the diameter of inclusions in hot bands. As discussed previously, the size of manganese sulfide inclusion increased with increasing hot band annealing temperature. Therefore, final grain size of lowcarbon electrical steels increased with increasing hot band annealing temperature. In this study, the effect of manganese sulfide inclusion size is more significant than hot band grain size. So that, the final grain size of low-carbon electrical steels increased with increasing hot band annealing temperature.

It is probable that some fine precipitates of aluminum nitrides come out in the hot band during annealing at $700^{\circ} \mathrm{C}$. Aluminum nitrides impede the grain growth of steel sheet during final annealing. Therefore, final grain size of steel without hot band annealing was larger than that of steel with hot band annealing at $700^{\circ} \mathrm{C}$.

\subsection{Texture}

The effect of hot band annealing temperature on the inverse pole intensities of $\{110\},\{200\},(211\}$ and $\{222\}$ crystallographic planes parallel to the steel sheet surface were shown in Figs. 5-8. As shown in Fig. 5, the inverse pole intensity $\left(I / I_{\mathrm{R}}\right)_{110}$ of low-carbon electrical steels rapidly increased with increasing hot band annealing temperature in the range of $700-800^{\circ} \mathrm{C}$. When hot bands were annealed at temperature higher than $800^{\circ} \mathrm{C}$, the inverse pole intensity of $\left(I / I_{\mathrm{R}}\right)_{110}$ approached a plateau. The inverse pole intensity $\left(I / I_{\mathrm{R}}\right)_{110}$ of steel without hot band annealing was almost equal to that of steel with hot band annealed at $700^{\circ} \mathrm{C}$. As shown in Fig. 6, the

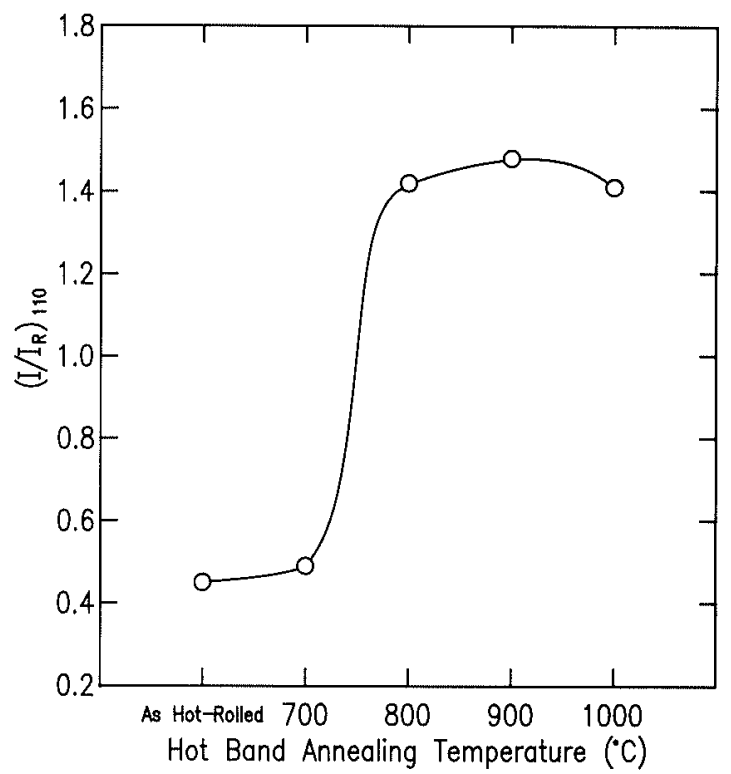

Fig. 5. Effect of hot band annealing temperature on inverse pole intensity $\left(I / I_{\mathrm{R}}\right)_{110}$ of low-carbon electrical steels.

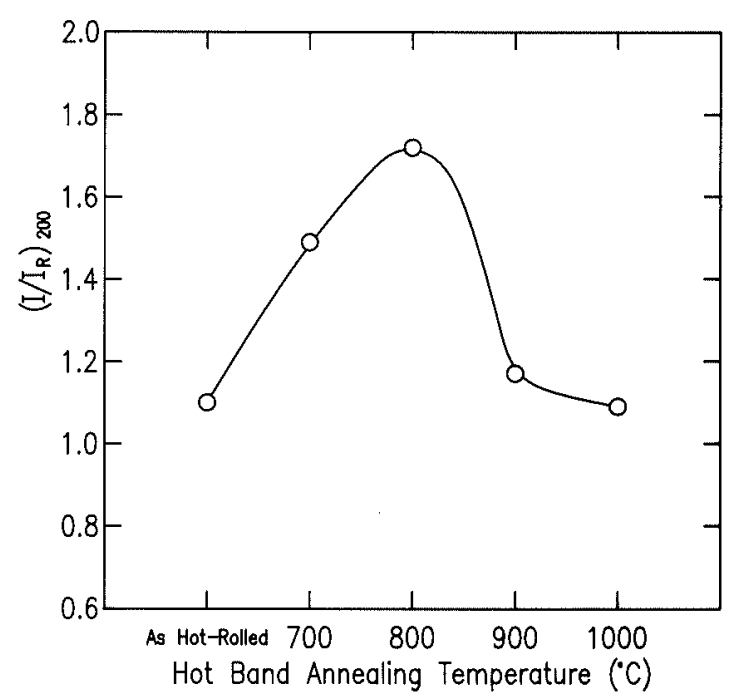

Fig. 6. Effect of hot band annealing temperature on inverse pole intensity $\left(I / I_{\mathrm{R}}\right)_{200}$ of low-carbon electrical steels.

inverse pole intensity $\left(I / I_{\mathrm{R}}\right)_{200}$ of low-carbon electrical steels initially increased with increasing hot band annealing temperature and reached a maximum value at $800^{\circ} \mathrm{C}$. After that, the inverse pole intensity $\left(I / I_{R}\right)_{200}$ of low-carbon electrical steels came down with increasing hot band annealing temperature. As shown in Fig. 7, the inverse pole intensity $\left(I / I_{\mathrm{R}}\right)_{211}$ of low-carbon electrical steels rapidly decreased with increasing hot band annealing temperature in the range of $700-800^{\circ} \mathrm{C}$. When hot band annealing temperature was higher than $800^{\circ} \mathrm{C}$, the inverse pole intensity $\left(I / I_{\mathrm{R}}\right)_{211}$ of low-carbon electrical steel linearly increased with increasing temperature. The inverse pole intensity $\left(I / I_{\mathrm{R}}\right)_{211}$ of steel without hot band annealing was almost equal to that of steel with hot band annealed at $700^{\circ} \mathrm{C}$. As shown in Fig. 8, the inverse pole intensity $\left(I / I_{\mathrm{R}}\right)_{222}$ of low-carbon electrical steels rapidly decreased with increasing hot band annealing temperature in the range of $700-800^{\circ} \mathrm{C}$. When hot band annealing temperature was higher than $800^{\circ} \mathrm{C}$, the inverse pole intensity $\left(I / I_{\mathrm{R}}\right)_{222}$ of low-carbon elec- 


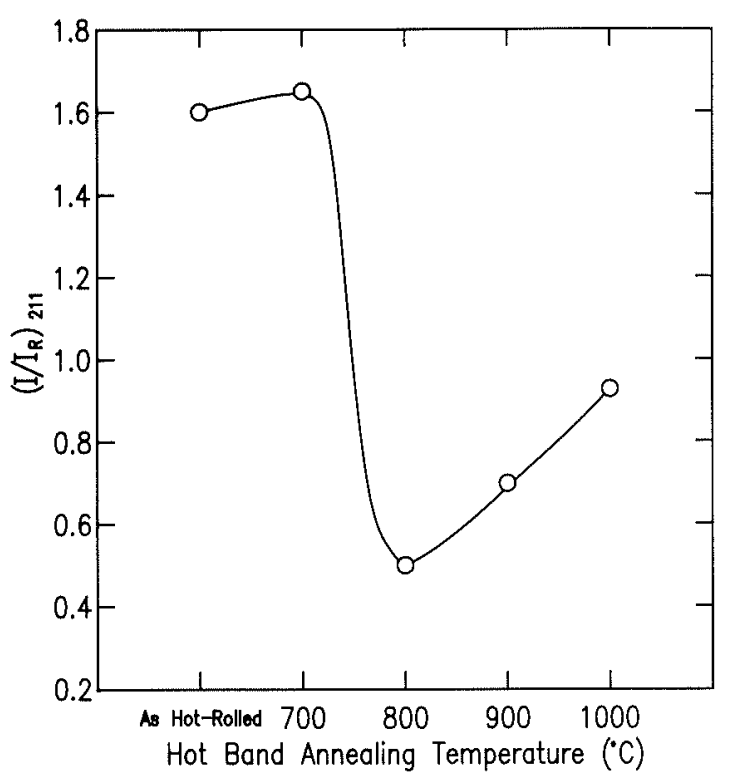

Fig. 7. Effect of hot band annealing temperature on inverse pole intensity $\left(I / I_{R}\right)_{211}$ of low-carbon electrical steels.

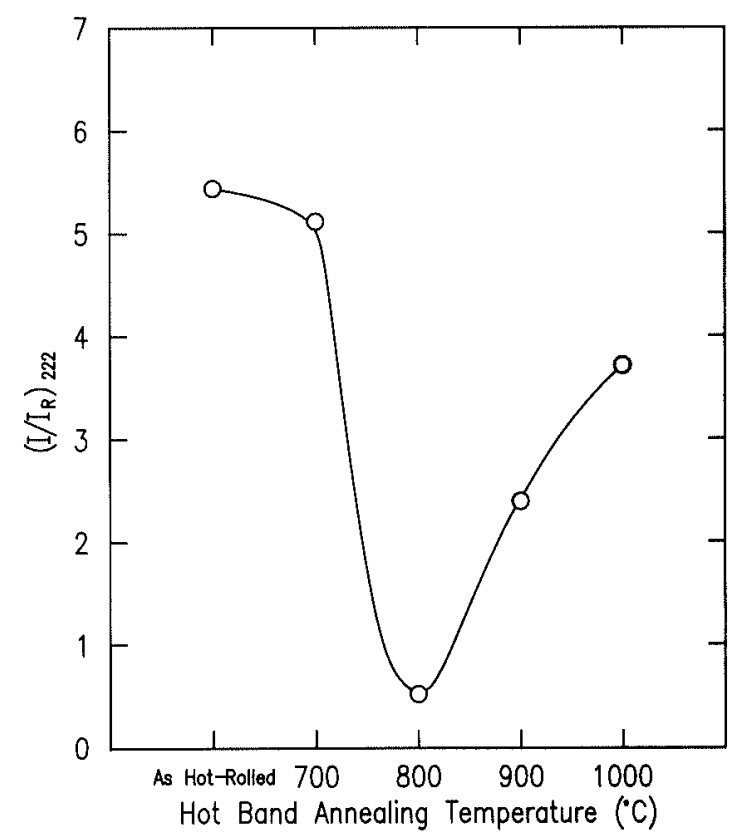

Fig. 8. Effect of hot band annealing temperature on inverse pole intensity $\left(I / I_{\mathrm{R}}\right)_{222}$ of low-carbon electrical steels.

trical steels linearly increased with increasing temperature. The trend of $\left(I / I_{\mathrm{R}}\right)_{222}$ with respect to hot band annealing temperature was similar to that of $\left(I / I_{R}\right)_{211}$.

It is well known that $\langle 100\rangle$ of bcc iron is the easy axis of magnetization. However, $\langle 111\rangle$ crystallographic axis is the hard axis of magnetization. Both $\{110\}$ and $\{200\}$ planes contain the easy magnetization axes and are favorable to the magnetic properties of low-carbon electrical steels. On the other hand, $\{211\}$ and $\{222\}$ planes do not contain the easy magnetization axes and are unfavorable to the magnetic properties of low-carbon electrical steels. As shown in Figs. 5-8, steel with hot band annealing at $800^{\circ} \mathrm{C}$ has strong texture components of $\left(I / I_{\mathrm{R}}\right)_{110}$ and $\left(I / I_{\mathrm{R}}\right)_{200}$ on one hand. It also has weak texture components of $\left(I / I_{\mathrm{R}}\right)_{211}$ and $\left(I / I_{\mathrm{R}}\right)_{222}$ on the other hand. Therefore, steel with hot band annealing at $800^{\circ} \mathrm{C}$

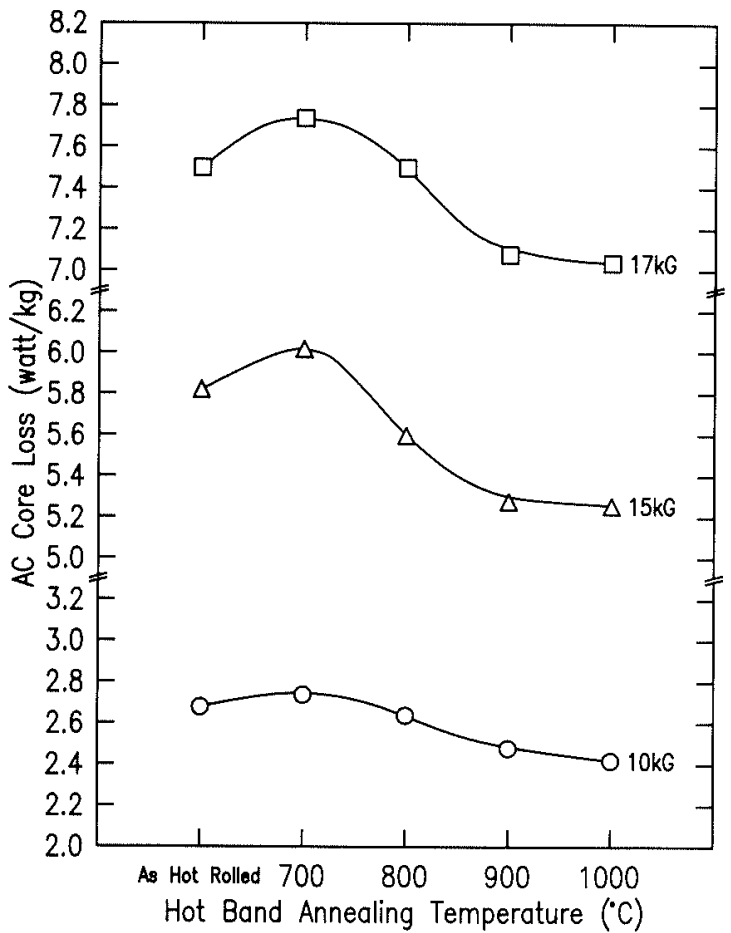

Fig. 9. Effect of hot band annealing temperature on the ac core loss of low-carbon electrical steels measured at 10,15 and $17 \mathrm{kG}$ inductions.

has favorable texture for magnetic properties.

\subsection{Magnetic Properties}

\subsubsection{Loss}

The effect of hot band annealing temperature on the ac core loss of low-carbon electrical steels measured at 10,15 and $17 \mathrm{kG}$ inductions after final annealing was shown in Fig. 9. At three different inductions, the trends of ac core loss with respect to hot band annealing temperature were similar. In temperature range of 700 $900^{\circ} \mathrm{C}$, ac core loss rapidly decreased with increasing hot band annealing temperaure. When hot band was annealed at temperature higher than $900^{\circ} \mathrm{C}$, ac core loss was almost leveled off. Ac core loss of steel without hot band annealing was a little lower than that of steel with hot band annealed at $700^{\circ} \mathrm{C}$. The effect of hot band annealing temperature on the hysteresis loss of lowcarbon electrical steels measured at 10,15 and $17 \mathrm{kG}$ inductions after final annealing was shown in Fig. 10. At three different inductions, the trends of hysteresis loss with respect to hot band annealing temperature were the same. In the temperature range of $700-900^{\circ} \mathrm{C}$, hysteresis loss rapidly decreased with increasing hot band annealing temperature. When hot band was annealed at temperature higher than $900^{\circ} \mathrm{C}$, hysteresis loss was almost leveled off. Hysteresis loss of steel without hot band annealing was a little lower than that of steel with hot band annealing at $700^{\circ} \mathrm{C}$. The effect of hot band annealing temperature on the apparent eddy current loss of lowcarbon electrical steels measured at 10,15 and $17 \mathrm{kG}$ inductions after final annealing was shown in Fig. 11. At the same induction, apparent eddy current loss of all steels was almost the same and was independent on the hot band annealing temperature.

Many factors, such as grain size, texture, impurities 


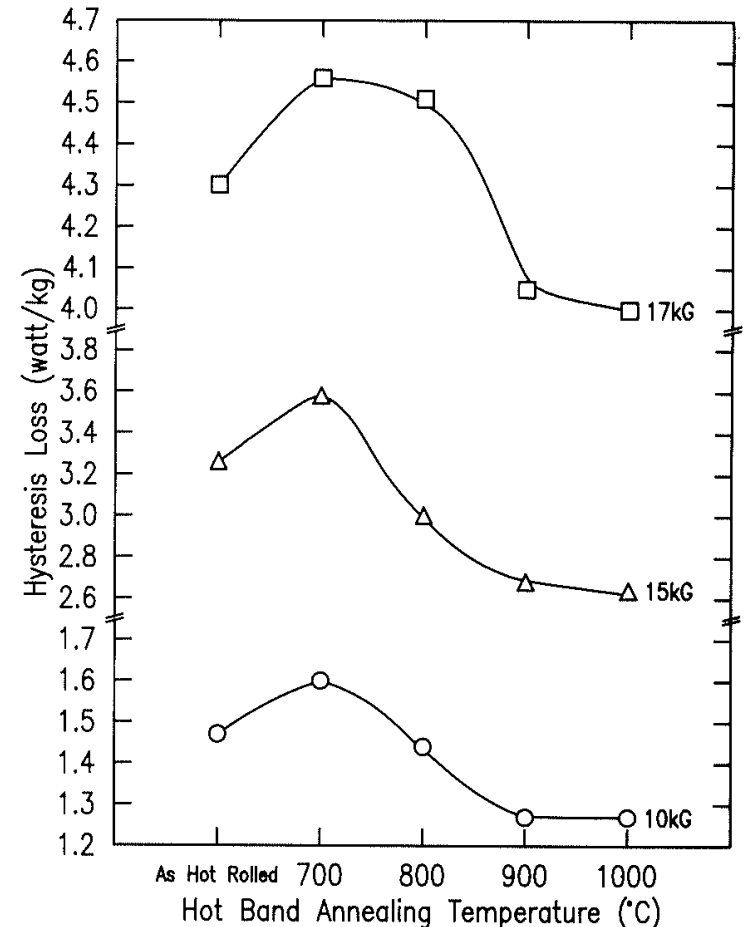

Fig. 10. Effect of hot band annealing temperature on the hysteresis loss of low-carbon electrical steels measured at 10,15 and $17 \mathrm{kG}$ inductions.

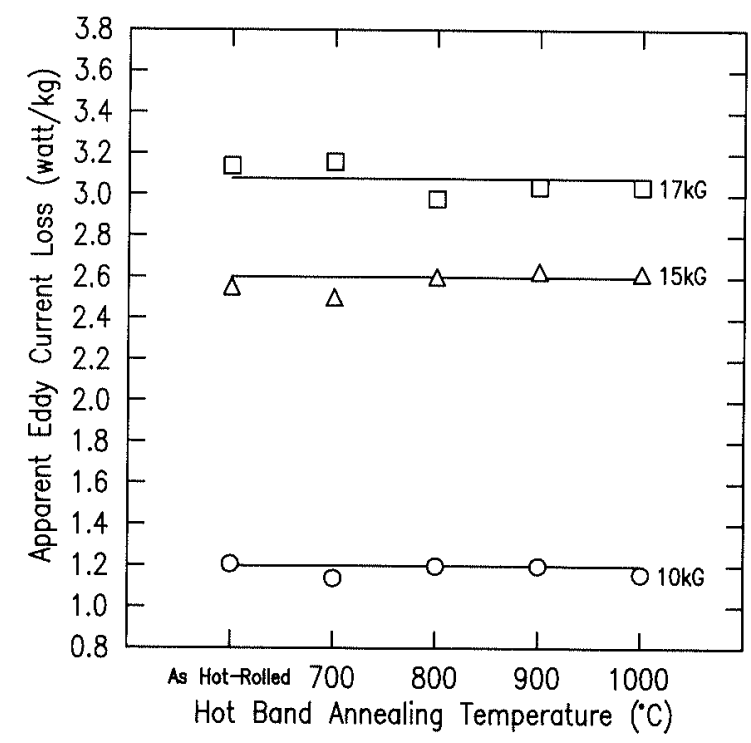

Fig. 11. Effect of hot band annealing temperature on the apparent eddy current loss of low-carbon electrical steels measured at 10,15 and $17 \mathrm{kG}$ inductions.

and inclusions affect the hysteresis loss of low-carbon electrical steels. In this study, the chemical composition of all steel sheets are the same. As shown in Table 1, the contents of carbon and nitrogen in the steels are very low. It is probable that most amount of carbon and nitrogen dissolve in the matrix during the final annealing. After final annealing, carbon and nitrogen tend to form carbide and nitride. Because the final annealing process of all specimens is the same, the amount of carbide and nitride are almost the same. In addition, oxide also formed in the steel after solidification. The amount of oxide did not change during the succeeding processes. With the above premise, the effects of carbide, nitride and oxide on the hysteresis loss of low-carbon electrical steels are almost the same. The nucleation and annihilation of accommodation domains at grain boundary is a source of hysteresis loss. ${ }^{12)}$ Thus hysteresis loss is high for small grain, low for large grain. As shown in Fig. 4, grain size of low-carbon electrical steels increased with increasing hot band annealing temperature. Therefore, increase of the hot band annealing temperature is beneficial to the hysteresis loss and ac core loss of low-carbon electrical steels as shown in Figs. 9 and 10 . Texture is another factor to influence hysteresis loss of low-carbon electrical steels. As discussed previously, $\left(I / I_{\mathrm{R}}\right)_{110}$ and $\left(I / I_{\mathrm{R}}\right)_{200}$ are favorable texture to low-carbon electrical steels. On the other hand, $\left(I / I_{\mathrm{R}}\right)_{211}$ and $\left(I / I_{\mathrm{R}}\right)_{222}$ are unfavorable texture to low-carbon electrical steels. As shown in Figs. 5-8, steel with hot band annealing at $800^{\circ} \mathrm{C}$ developed the most favorable texture for magnetic properties. When hot band was annealed at temperature higher than $800^{\circ} \mathrm{C}$, unfavorable texture for magnetic properties developed with increasing temperature. The texture of steel without hot band annealing and steel with hot band annealed at $700^{\circ} \mathrm{C}$ was poorer than that of steel with hot band annealed at temperature higher than $800^{\circ} \mathrm{C}$. Manganese sulfide inclusion size is another factor to affect the hysteresis loss of low-carbon electrical steels. Larger manganese sulfide inclusion is less harmful to hysteresis loss. Comparing Figs. 4 with 10, it is known that hysteresis loss decreased with increasing grain size. This indicates that the effect of grain size and manganese sulfide inclusion size on the hysteresis loss are more significant than that of texture. Classical eddy current loss is inverse proportional to the electrical resistivity and proportional to the square of thickness. ${ }^{23)}$ Electrical resistivity of electrical steel is directly related to its chemical composition. ${ }^{24)}$ Since chemical composition and thickness of all steel sheets are the same, the electrical resistivity and classical eddy current loss are also the same. The final grain size of continuous annealed low-carbon electrical steels is relative small. The difference of anomalous loss was not obvious. Apparent eddy current loss is the sum of classical eddy current loss and anomalous loss. Therefore, the apparent eddy current losses of all steels were similar and independent on the hot band annealing temperature. The trend of ac core loss with respect to hot band annealing temperature is similar to that of hysteresis loss. Moreover, grain size of steel without hot band annealing was larger than that of steel with hot band annealed at $700^{\circ} \mathrm{C}$. The hysteresis loss and ac core loss of steel without hot band annealing was lower than that of steel with hot band annealed at $700^{\circ} \mathrm{C}$.

\subsubsection{Permeability}

The effect of hot band annealing temperature on the ac permeability of low-carbon electrical steels measured at 10,15 and $17 \mathrm{kG}$ inductions after final annealing was shown in Fig. 12. At three different inductions, the trends of ac permeability with respect to hot band annealing temperature were different. At $10 \mathrm{kG}$ induction, ac permeability rapidly increased with increasing hot band annealing temperature in the range of $700-800^{\circ} \mathrm{C}$. Then, 


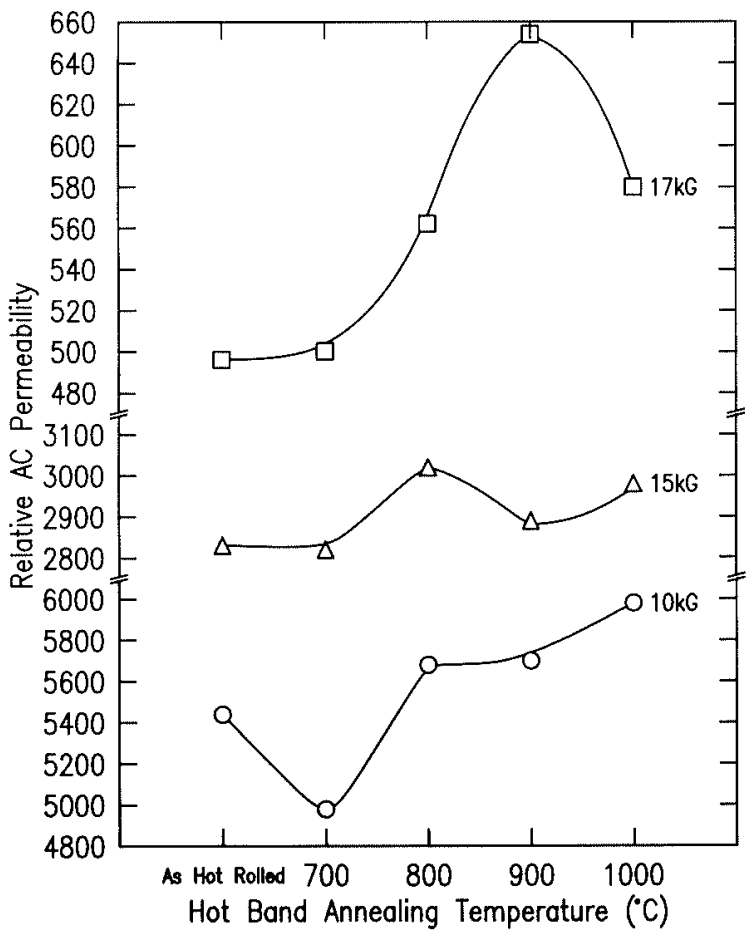

Fig. 12. Effect of hot band annealing temperature on the ac permeability of low-carbon electrical steels measured at 10,15 and $17 \mathrm{kG}$ inductions.

ac permeability slightly increased with increasing hot band annealing temperature in the range of $800-1000^{\circ} \mathrm{C}$. Ac permeability of steel without hot band annealing was larger than that of steel with hot band annealed at $700^{\circ} \mathrm{C}$. At $15 \mathrm{kG}$ induction, ac permeability increased with increasing hot band annealing temperature and reached a maximum value at $800^{\circ} \mathrm{C}$. Then, ac permeability came down with increasing temperature and stopped at $900^{\circ} \mathrm{C}$. When hot band annealing temperature was higher than $900^{\circ} \mathrm{C}$, ac permeability slightly increased with increasing temperature again. Ac permeability of steel without hot band annealing was almost equal to that of steel with hot band annealed at $700^{\circ} \mathrm{C}$. At $17 \mathrm{kG}$ induction, ac permeability rapidly increased with increasing hot band annealing temperature and reached a maximum value at $900^{\circ} \mathrm{C}$. Then, ac permeability came down with increasing temperature. Ac permeability of steel without hot band annealing was almost the same to that of steel with hot band annealed at $700^{\circ} \mathrm{C}$. The effect of hot band annealing temperature on the dc permeability of low-carbon electrical steels measured at 10,15 and $17 \mathrm{kG}$ inductions after final annealing was shown in Fig. 13. At the same induction, the trend of dc permeability respect to hot band annealing temperature was similar to that of ac permeability.

Both grain size and texture affect the magnetization behaviors and permeability of low-carbon electrical steels. When comparing grain size and permeability in Figs. 4, 12 and 13, ac and dc permeability increased with increasing grain size under $10 \mathrm{kG}$ induction. This suggests that the effect of grain size on permeability is more significant than that of texture. At $15 \mathrm{kG}$ induction, the effect of texture on permeability became important. Because of the combined effect of texture and grain size

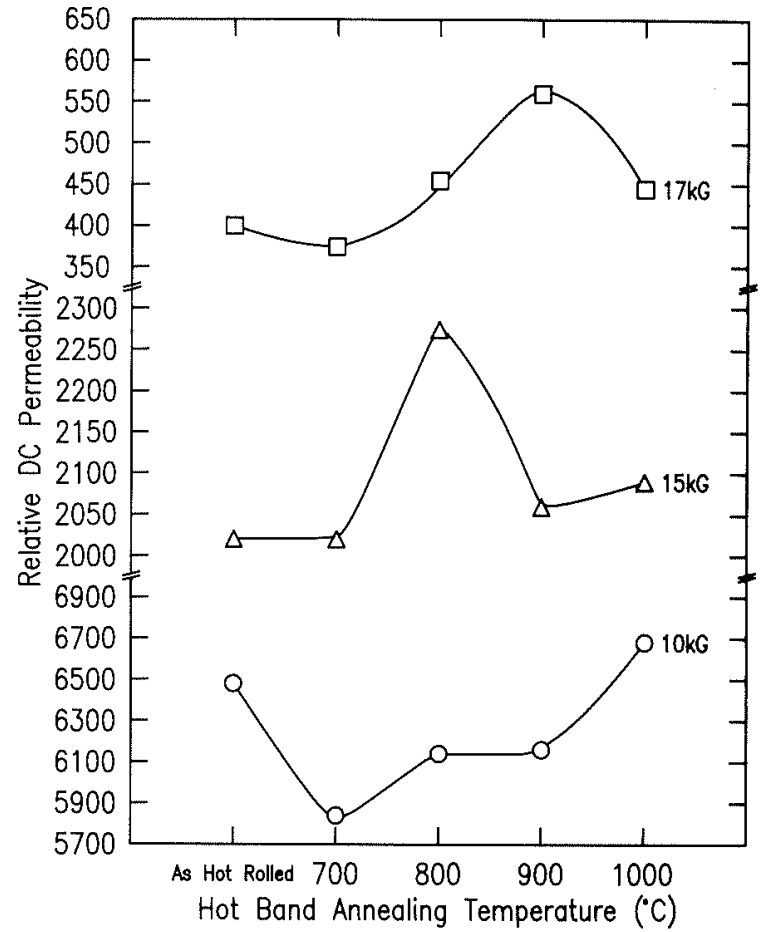

Fig. 13. Effect of hot band annealing temperature on the dc permeability of low-carbon electrical steels measured at 10,15 and $17 \mathrm{kG}$ inductions.

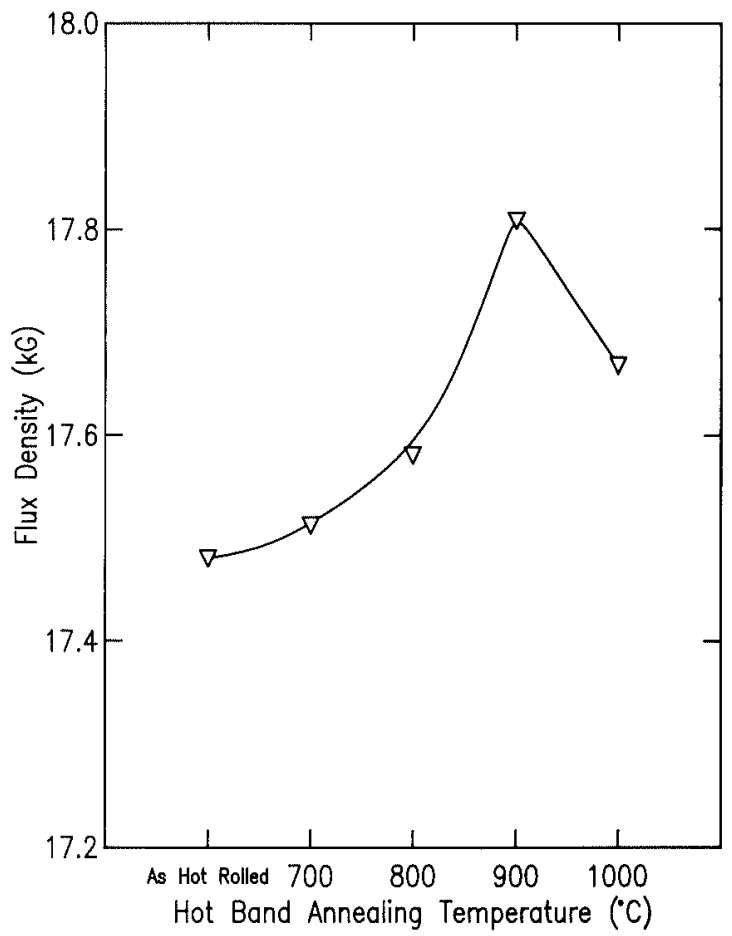

Fig. 14. Effect of hot band annealing temperature on the magnetic flux density of low-carbon electrical steels measured at 10,15 and $17 \mathrm{kG}$ inductions.

steel with hot band annealing at $800^{\circ} \mathrm{C}$ obtained a maximum permeability at $15 \mathrm{kG}$ induction. However, steel with hot band annealing at $900^{\circ} \mathrm{C}$ obtained a maximum permeability at $17 \mathrm{kG}$ induction.

\subsubsection{Magnetic flux density}

The effect of hot band annealing temperature on the magnetic flux density of low-carbon electrical steels measured at $5000 \mathrm{~A} / \mathrm{M}$ magnetic field strength after final 
annealing was shown in Fig. 14. Magnetic flux density rapidly increased with increasing hot band annealing temperature and reached a maximum value at $900^{\circ} \mathrm{C}$. Then, magnetic flux density came down with increasing temperature. Magnetic flux density of steel without hot band annealing was smaller than that of steel with hot band annealed at $700^{\circ} \mathrm{C}$.

Both grain size and texture affect the magnetization behaviors and magnetic flux density of low-carbon electrical steels. Because of the combined effect of grain size and texture, low-carbon electrical steel with hot band annealed at $900^{\circ} \mathrm{C}$ obtained maximum magnetic flux density.

\section{Conclusion}

The effect of hot band annealing temperature, range from $700-1000^{\circ} \mathrm{C}$, on the magnetic properties of lowcarbon electrical steels measured at 10,15 and $17 \mathrm{kG}$ inductions have been investigated. The results are summarized as follows:

(1) The grain structure and size of manganese sulfide inclusions of hot bands were changed by annealing at various temperature. Small grains are observed in the as hot-rolled band and hot band annealed at $700^{\circ} \mathrm{C}$. Large columnar grains are observed in the hot band annealed at $800^{\circ} \mathrm{C}$. Duplex structure with fine grains at the central portion of the plate and large columnar grains near the surface are observed in the hot band annealed at $900^{\circ} \mathrm{C}$. Uniform medium size grains are observed in the hot band annealed at $1000^{\circ} \mathrm{C}$. The size of manganese sulfide inclusions in hot bands increased with increasing annealing temperature.

(2) After final annealing at $820^{\circ} \mathrm{C}$ for $1 \mathrm{~min}$, grain size of low-carbon electrical steels increased with increasing hot band annealing temperature due to the combined effect of hot band grain size and the size of manganese sulfide inclusions. After final annealing, low-carbon electrical steel with hot band annealing at $800^{\circ} \mathrm{C}$ developed the most favorable texture for magnetic properties.

(3) Ac core loss and hysteresis loss of low-carbon electrical steels rapidly decreased with increasing hot band annealing temperature in the range of $700-900^{\circ} \mathrm{C}$. The effect of grain size and manganese sulfide inclusion size on hysteresis loss of low-carbon electrical steels are more significant than that of texture. At the same induction, apparent eddy current loss of all steels was similar and was independent on hot band annealing temperature.

(4) Because of the significant effect of grain size, ac and dc permeability of low-carbon electrical steel increased with increasing hot band annealing temperature at $10 \mathrm{kG}$ induction. Due to the combined effect of grain size and texture, low-carbon electrical steel with hot band annealing at $800^{\circ} \mathrm{C}$ exhibited maximum ac and dc permeability at $15 \mathrm{kG}$ induction. At $17 \mathrm{kG}$ induction, low-carbon electrical steel with hot band annealing at $900^{\circ} \mathrm{C}$ obtained maximum ac and dc permeability.

(5) Because of the combined effect of grain size and texture, low-carbon electrical steel with hot band annealing at $900^{\circ} \mathrm{C}$ obtained maximum magnetic flux density. When it was compared with the as hot-rolled steel, hot band annealing at temperature higher than $800^{\circ} \mathrm{C}$ improved the magnetic properties of low-carbon electrical steels.

\section{Acknowledgments}

The author would like to thank Dr. J. C. Tsou and Dr. G. H. Cheng of China Steel Corporation for their kind assistance. The work was supported by the National Science Council, Taiwan, Republic of China through the grant no. NSC84-2216-E-224-001.

\section{REFERENCES}

1) F. E. Werner: Electrical Steels: 1970-1990, in Energy Efficient Electrical Steels, ed. by A. R. Marder and E. T. Stephenson, The Metall. Soc., Warrendale, PA, (1981), 1.

2) F. E. Werner and R. I. Jaffee: J. Mater. Eng. Performance, 1 (1992), No. 2, 227.

3) P. Arato, I. Boc and T. Grof: J. Magn. Magn. Mat., 41 (1984), 53.

4) P. Brissonneau: J. Magn. Magn. Mat., 19 (1980), 52

5) K. C. Liao: Metall. Trans., 17A (1986), 1259.

6) Y. Shimoyama, et al.: IEEE Trans. Magn., MAG-19 (1983), 2013.

7) K. Gunther, F. Bolling and H. Huneus: J. Appl. Phys., 64 (1988), 5347.

8) K. Ueno, I. Tachino and T. Kubota: Advantages of VacuumDegassing of Nonoriented Electrical Steels, in Metallurgy of Vacuum-Degassed Carbon-Steel Products, ed. by R. Pradhan, The Metall. Soc., Warrendale, PA, (1990), 347.

9) M. Jitsukawa, M. Mitsunari, S. Tanabe, Y. Okami, K. Sekiguchi, Y. Hosoya and A. Furuda: NKK Tech. Rev., (1990), No. 60, 16

10) P. L. Charpentier and J. H. Bucher: Mechanical Working and Steel Processing X, AIME, (1972), 61.

11) E. T. Stephenson and M. R. Amann: Effects of Composition, Grain Size and Texture on the AC Core Loss of Magnetic Lamination Steel, ed. by A. R. Marder and E. T. Stephenson, The Metall. Soc., Warrendale, PA, (1981), 43.

12) E. T. Stephenson and A. R. Marder: IEEE Trans. Magn., MAG-22 (1986), 101.

13) P. R. Mould and R. R. Judd: Mechanical Working and Steel Processing XXII, AIME, (1984), 235.

14) G. Lyudkovsky and P. D. Southwick: Metall. Trans. A., 17A (1986), 1267

15) H. Yashiki and A. Okamoto: IEEE Trans. Mag., MAG-23, (1987), 3086.

16) C. K. Hou, C. T. Hu and S. Lee: J. Mater. Sci. Eng., A125 (1990), 241.

17) C. K. Hou, C. T. Hu and S. Lee: J. Magn. Magn. Mater., 87 (1990), 44.

18) C. K. Hou and P. C. Wang: J. Magn. Magn. Mater, 92 (1990), 109.

19) C. K. Hou, C. T. Hu and S. Lee: IEEE Trnas. Magn., MAG-27 (1991), 4305

$20)$ C. K. Hou, C. T. Hu and S. Lee: J. Magn. Magn. Mater., 109 (1992), 7.

21) C. K. Hou and S. Lee: IEEE Trans. Magn., MAG-30 (1994), 212

22) C. S. Smith: Trans. Metall. Soc. AIME, 175 (1949), 15.

23) E. W. Golding: Electrical Measurements and Measuring Instruments, 4th Ed., Pitmans and Sons, London, (1961), 913.

24) M. F. Littmann: IEEE Trans. Magn., MAG-7 (1971), 48. 